American Journal of Environmental Sciences 5 (5): 653-656, 2009

ISSN 1553-345X

(C) 2009 Science Publications

\title{
Biodegradation and Recycling of Urban Solid Waste
}

\author{
${ }^{1}$ S.P. Gautam, ${ }^{2}$ P.S. Bundela, ${ }^{3}$ A.K. Pandey, ${ }^{4}$ R.K. Jain, ${ }^{2}$ P.R. Deo, \\ ${ }^{2}$ S.K. Khare, ${ }^{2}$ M.K. Awasthi and ${ }^{2}$ Surendra Sarsaiya \\ ${ }^{1}$ Chairman Central Pollution Control Board, New Delhi, India \\ ${ }^{2}$ Regional Office Madhya Pradesh Pollution Control Board, Vijay Nagar Jabalpur, India \\ ${ }^{3}$ Mycological Research Laboratories, Department of Biological Sciences, Rani Durgavati University, \\ Jabalpur-482001, India
}

\begin{abstract}
Problem statement: Rapid urbanization and population growth are largely responsible for very high increasing rate of solid waste in the urban areas, its proper management and recycling is major problems of Municipal Corporation. The proposed study attempted to proper management, physicochemical analysis of Urban Solid Waste (USW) and its conversion to enriched compost by ecofriendly process. Approach: For this study, we used turned windrows method for composting of USW, microbial inoculums added uniformly and temperature, $\mathrm{pH}$, moisture maintained throughout the composting process. The chemical composition of compost obtained at the end of the composting process compare to the United State Environmental Protection Agency (USEPA) standards. Results: A study in Jabalpur had shown the 47\% of Urban Solid Waste (USW) were degradable and 53\% nondegradable. The initial compositions of urban waste were indicates an organic carbon status of $38 \%$ with the $\mathrm{C}: \mathrm{N}$ ratio of 950 . The additives used in solid urban waste composting such as cow dung and green manure recorded organic carbon content of 25.60 and 34.60 and $\mathrm{C}: \mathrm{N}$ ratio of 30.11 and 11.23. Conclusion: The results of the study clearly indicate that the recycling of solid urban waste can transform garbage or municipal solid waste to enriched composts. This is practical significance if adopted by urban farmers as a result of soil health and in turn the productivity of soil can be maintained for further agriculture.
\end{abstract}

Key words: Solid urban waste, coir dung, green manure, coir pith, bio conversion and nutrients

\section{INTRODUCTION}

The need of the hour is to improve soil health by providing the much needed organic matter, least soil become impoverished. The scope and potential for recycling variety of resources in agriculture is vat by any standards. Wastes recycling can bring tremendous benefits to agriculture and land management in long run. In addition there are the benefits of a cleaner environment, a healthier habitat and an intelligent use of all available recyclable resources without condemning them as wastes. Towards this end urban solid waste compost could serve as a valuable organic matter source given the shortage of organic nutrient source $\mathrm{e}^{[1]}$.

Defining quality standards for organic manures is a very difficult task given the heterogeneity of residues that occur in city wastes and processing methods adopted. Integrated nutrient management combining both inorganic and organics resulting in wholesome improvement of the soil. Faced with such situation utilizing valuable urban resources for manure production would be viable alternative given the ever increasing urban status resulting in urban waste production. This can be done by adopting the technology of "composting" refers is a biological process in which organic urban solid waste material is broken down by the action of microorganisms. The degradation process takes place in the presence of air (aerobic) and results in elevated process temperature and the production of $\mathrm{CO}_{2}$, water and stabilized organic residue. The key feature of the composting process is the generation of heat by biological activity during the decomposition of the substrate materials. By forming the waste into large masses under appropriate conditions, they will reach high temperature, resulting in rapid degradation. More importantly, these temperature have a sanitizing effect upon the waste, reducing the numerous of pathogenic $\operatorname{organism}^{[3]}$.

Corresponding Author: P.S. Bundela, Regional Office MP Pollution Control Board, Vijay Nagar Jabalpur (MP) India Tel: +91-0761-4042780 Fax: +91-0761- 4042780 
Keeping in view, the benefits of organic manuring as well as its inherent limitations such as analysis and slow action, a study was taken up to investigate the possibility of conversion of solid urban waste into enriched compost and to evaluate their nutritional quality.

\section{MATERIALS AND METHODS}

The investigation on the Biodegradation and recycling of urban wastes includes characterization of ingredients; composting and testing the components in the field were done at Regional office MP pollution control board and mycological research laboratory RDV University, Jabalpur (MP). The man raw materials used for preparation of compost were urban wastes, farm wastes and weeds. City garbage wastes from Jabalpur consisted of vegetables, fruits, plant and other kitchen wastes besides, few glass pieces, plastics, and metal pieces. The extraneous material was removed manually from the garbage. Additives used in the experiment are green leaves and tender shoots of parthenium, lantana camara, cow dung, coir pith, rock phosphate, urea, micronutrients and microbial inoculum such as Trichoderma sp.

Characterization of organic materials used for composting: The organic wastes collected from different sources were analyzed for $\mathrm{pH}$, electrical conductivity, organic carbon, total nitrogen, total phosphorus, total potassium using standard procedures $^{[4]}$ and total micronutrients were analyzed by standard procedure given by ${ }^{[5]}$ using inductively coupled plasma emission spectroscopy (ICAP).

Treatments adopted for composting and composting methods: For the preparation of compost, followed the Turned Windrows method as per as ${ }^{[6]}$. Under this process the urban waste were manually separated and then piles of mixed solid waste of 3'X5' (height $\mathrm{x}$ width) were used and the required operating condition of moisture, temperature, air were maintained throughout the composting as per as standard process ${ }^{[7]}$. Microbial inoculants and chopped garden weeds were added uniformly.

\section{RESULTS}

Organic matter recycling is a vital for supplementing plant nutrients and maintenance of soil productivity. Organic matter resources have therefore to be identified, characterized and utilized in the crop production practices suitably. Large quantities of waste materials are they originated from forms and agro based units or from industries need to be evaluated to meet plant nutrient requirements.

Physical composition of solid urban wastes: Municipal solid waste composition was observed very demographically. Prior to segregation, the solid urban wastes consisted of some reusable material such as plastic, metals, glass and paper which totally constituted to about $53 \%$. This was separated and further used in recycling industries. Vegetable matter and other decomposable is the predominant constituent which are present to an extent of $47 \%$.

Chemical composition of organic wastes: The chemical compositions of various organic materials used for preparing the compost are given in Table 1. Urban waste is one of the potential nutrient organic residues, which on recycling yield valuable and nutrient rich product known as compost. The urban waste is found to be slightly alkaline in nature $(\mathrm{pH} 7.76)$ and was fairly low in $\mathrm{N}(0.04 \%), \mathrm{P}(0.00018 \%)$, fairly rich in $\mathrm{K}(0.35 \%)$ and Sodium $(3.4 \%)$. The organic carbon was $38 \%$ with a $\mathrm{C}: \mathrm{N}$ ratio of 950:0.04. Green leaves were rich in $\mathrm{N}(0.75 \%)$ and was used to supplement $\mathrm{N}$ to initially counter the nitrogen depletion. Cow dung used as an additive or inoculum for the compost treatments. This mainly served as a starter material for composting. It also enhances the decomposition of cellulosic plant material ${ }^{[8]}$ and it had $0.85 \% \mathrm{~N}$ with a $\mathrm{C}: \mathrm{N}$ ratio of 30.11 .

Table 1: Chemical composition of raw materials used for composting

\begin{tabular}{lrrr}
\hline Characteristics & Urban waste & Cow dung & Green leaves \\
\hline $\mathrm{pH}$ & 7.7600 & 7.10 & 7.32 \\
$\mathrm{EC}\left(\mu \mathrm{s} \mathrm{cm}^{-1}\right)$ & 1445.0000 & 1363.00 & 1296.00 \\
Organic carbon (\%) & 38.0000 & 25.60 & 34.60 \\
Nitrogen $(\%)$ & 0.0400 & 0.85 & 3.08 \\
Phosphorus (\%) & 0.0018 & 0.27 & 0.14 \\
Potassium (\%) & 0.3500 & 0.36 & 1.65 \\
Sodium $(\%)$ & 3.4000 & 2.26 & 1.63 \\
$\mathrm{C}: \mathrm{N} \mathrm{ratio}$ & 950.0000 & 30.11 & 11.23 \\
$\mathrm{Cr}\left(\mathrm{mg} \mathrm{kg}^{-1}\right)$ & 22.4000 & 12.50 & 18.30 \\
$\mathrm{Cd}\left(\mathrm{mg} \mathrm{kg}^{-1}\right)$ & 0.2000 & 0.04 & 0.01 \\
$\mathrm{Cu}\left(\mathrm{mg} \mathrm{kg}^{-1}\right)$ & 65.3600 & 24.50 & 54.30 \\
$\mathrm{Fe}\left(\mathrm{mg} \mathrm{kg}^{-1}\right)$ & 14060.0000 & 1225.00 & 14253.00 \\
$\mathrm{Zn}\left(\mathrm{mg} \mathrm{kg}^{-1}\right)$ & 70.4000 & 48.20 & 52.70 \\
$\mathrm{Mn}\left(\mathrm{mg} \mathrm{kg}^{-1}\right)$ & 356.0000 & 244.00 & 274.00 \\
$\mathrm{Ni}\left(\mathrm{mg} \mathrm{kg}^{-1}\right)$ & 43.6000 & 24.30 & 22.60 \\
$\mathrm{~Pb}\left(\mathrm{~m} \mathrm{~kg} \mathrm{~kg}^{-1}\right)$ & 22.2000 & 2.52 & 14.52 \\
\hline
\end{tabular}


Am. J. Environ. Sci., 5 (5): 653-656, 2009

Table 2: Chemical properties of the matured solid urban waste compost

\begin{tabular}{|c|c|c|c|c|c|c|}
\hline Characteristics & $\mathrm{C} 1$ & $\mathrm{C} 2$ & $\mathrm{C} 3$ & $\mathrm{C} 4$ & $\mathrm{C} 5$ & C6 \\
\hline$\overline{\mathrm{pH}}$ & 7.0200 & 7.5300 & 7.5600 & 7.1700 & 7.1000 & 7.5400 \\
\hline $\left.\mathrm{EC}(\mu \mathrm{s} \mathrm{cm})^{-1}\right)$ & 1439.0000 & 1363.0000 & 1151.0000 & 1445.0000 & 1425.0000 & 1439.0000 \\
\hline Organic carbon $(\%)$ & 38.0000 & 28.0000 & 32.0000 & 37.0000 & 33.0000 & 39.0000 \\
\hline Nitrogen $(\%)$ & 0.0400 & 0.0600 & 0.0600 & 0.0500 & 0.0500 & 0.0700 \\
\hline Phosphorus (\%) & 0.0018 & 0.0020 & 0.0006 & 0.0016 & 0.0022 & 0.0054 \\
\hline Potassium (\%) & 0.3500 & 0.4500 & 0.3000 & 0.4000 & 0.4000 & 0.4500 \\
\hline Sodium (\%) & 3.4000 & 4.9000 & 3.8000 & 5.7000 & 5.4000 & 4.3000 \\
\hline $\mathrm{C}: \mathrm{N}$ ratio & 950.0000 & 466.6600 & 533.3300 & 740.0000 & 660.0000 & 557.1400 \\
\hline $\mathrm{Cr}\left(\mathrm{mg} \mathrm{kg}^{-1}\right)$ & 22.4000 & 33.6000 & 30.4000 & 28.2000 & 29.0000 & 21.4000 \\
\hline $\mathrm{Cd}\left(\mathrm{mg} \mathrm{kg}^{-1}\right)$ & 0.2000 & $\mathrm{BDL}$ & 0.2000 & BDL & 0.4000 & 0.8000 \\
\hline $\mathrm{Cu}\left(\mathrm{mg} \mathrm{kg}^{-1}\right)$ & 65.3600 & 101.8800 & 97.1600 & 45.3200 & 43.7000 & 46.1600 \\
\hline $\mathrm{Fe}\left(\mathrm{mg} \mathrm{kg}^{-1}\right)$ & 14060.0000 & 16180.0000 & 19180.0000 & 19720.0000 & 18460.0000 & 14460.0000 \\
\hline $\mathrm{Zn}\left(\mathrm{mg} \mathrm{kg}^{-1}\right)$ & 70.4000 & 95.0000 & 34.0000 & 61.6000 & 78.4000 & 63.4000 \\
\hline $\operatorname{Mn}\left(\mathrm{mg} \mathrm{kg}^{-1}\right)$ & 244.0000 & 356.0000 & 280.0000 & 274.0000 & 256.0000 & 267.0000 \\
\hline $\mathrm{Ni}\left(\mathrm{mg} \mathrm{kg}^{-1}\right)$ & 43.6000 & 56.4000 & 41.0000 & 57.6000 & 47.6000 & 42.6000 \\
\hline $\mathrm{Pb}\left(\mathrm{mg} \mathrm{kg}^{-1}\right)$ & 22.2000 & 26.8000 & 19.4000 & 10.2000 & 14.8000 & 12.6000 \\
\hline
\end{tabular}

Chemical characteristics of the matured solid urban waste compost: The data on chemical properties of the matured solid urban waste composts are given in Table 2. The $\mathrm{pH}$ of all the composts was neutral to slightly alkaline. This may be due to the natural buffering of the humus. Highest $\mathrm{pH}$ was recorded in $\mathrm{C} 3$ compared to others. The results in the present study concurred with the observation of ${ }^{[9]}$ who reported that the municipal compost was slightly alkaline in nature and had a marked buffering capacity. The percent organic carbon varied between his treatments. The $\mathrm{N}$ content was highest in C6 compared to all other composts which was due to high $\mathrm{N}$ content in the raw materials. The enrichment of urban waste with rock phosphate yielded composts with high $\mathrm{P}$ content.

The enrichment of compost with additives increased the decomposition rate, which may be due to availability of essential nutrients for the increased biological activity. From this investigation it can be stated that enrichment of urban waste with cow dung, rock phosphate, organic nitrogen, microbial culture and micronutrients resulted in value added compost. According to ${ }^{[10]}$ enrichment of compost with nutrients like $\mathrm{P}$ in the form of rock phosphate resulted in high value compost due to higher degree of decomposition.

\section{DISCUSSION}

Data from the research showed that proportioning of mixed wastes had resulted to desirable $\mathrm{C} / \mathrm{N}$ ratio (950:000) as generally not agreed by many researchers ${ }^{[11,12,15]}$, moisture about $65 \%$ and temperature $60^{\circ} \mathrm{C}$ were maintained which had been recommended by other researchers for composting process ${ }^{[11,12,14]}$. Achievement to maximum temperature (over $55^{\circ} \mathrm{C}$ ) in windrow systems in related times 6 day ensured hygienic charteristic of compost and destruction of pathogen and parasite according to $\mathrm{WHO}$ criteria ${ }^{15}$ and USEPA regulations for PSRP and condition in windrows composting system, according to PFRP regulations of U.S.EPA ${ }^{[13]}$. Measurement in both systems showed that, moisture content in sctive phase of composting process did not reach to less than desirable level, $50-60 \%$ process $^{[11,12,14]}$ and depleted phase. $\mathrm{pH}$ in mixed wastes was 7.2 and after starting up of the processes, decreased to about 5.5 and in compost product reached 07.7 in windrow which were accordance with ${ }^{[16]}$.

Physicochemical analysis of compost from the point of view N, P, K, Na Organic Carbon, Organic matter and heavy metals $(\mathrm{Cd}, \mathrm{Cr}, \mathrm{Fe}, \mathrm{Cu}, \mathrm{Zn}, \mathrm{Mn}, \mathrm{Ni}$ and $\mathrm{Pb}$ ) agreed with WHO criteria ${ }^{[15]}$ and USEPA. The data presented in table 2 showed that the windrows system was more effective for nutrients marinating.

Considering the high volume of garbage or MSW in Jabalpur, aerobic composting may be considered as an important it could be concluded that element of MSW management. In this regard, windrow system may be recommended for better method for recycling of MSW.

\section{CONCLUSION}

The results of the study clearly indicate that the Biodegradation and recycling of solid urban wastes can transform garbage to enriched composts. This is an important message of practical significance if adopted by urban farmers. Thereby the soil health and in turn the productivity of soil can be maintained for feature agriculture. This point gains importance given the fact that the quantum of cultivable land around Jabalpur is fast dwindling. Therefore the essence of the present study is that the urban farmers should be motivated to 
practice urban waste recycling through bioremedial measures.

\section{ACKNOWLEDGEMENT}

The researchers are thankful to Madhya Pradesh M.P. Pollution Control Board Bhopal and Head, Department of Biological Sciences, R.D. University, Jabalpur, for laboratory facilities. Also thanks to Municipal Corporation of Jabalpur for his support. Ministry of Environment and Forest New Delhi is also thankfully acknowledged for financial support.

\section{REFERENCES}

1. Prakash, U.H.B., M.V. Bhargavi, V.R.R. Parama and D.C. Preethu, 2007. Bioremedial recycling of solid waste. Proceeding of the International Conference on Sustainable Solid Waste Management, Sept. 5-7, Chennai, India, pp: 289-295. http://www.swlf.ait.ac.th/IntlConf/Data/ICSSWM \%20web/FullPaper/Session\%20V\%20B/5_B9\%20 _Bhanuprakash_.pdf

2. Xi, B., Z. Wei and H. Liu, 2005. Dynamic simulation for domestic solid waste composting processes. J. Am. Sci., 1: 34-45. http://www.americanscience.org/journals/amsci/0101/06-xibeidou.pdf

3. Iyenger, S.R. and P.P. Bhave, 2005. In-vessel composting of household wastes. Waste Manage., 26: 1070-1080.

http://cat.inist.fr/?aModele $=$ afficheN\&cpsidt $=1810$ 0237

4. Jackson, M.L., 1973. Soil Chemical Analysis. Prentice Hall, New Delhi, pp: 485.

5. Wong, S.Y. and S.S. Lin, 2002. Composts as sol supplement enhance plant growth and fruit quality of straw berry. J. Plant Nutr., 25: 2243-2259. http://cat.inist.fr/?aModele $=$ afficheN\&cpsidt $=1391$ 5337

6. Fleming, G., 2001. Municipal Solid Waste Composting Facility Operators Reference Guide and Handbook. pp: 23-45.
7. Hassen, A., K. Belguith, N. Jedidi, A. Cherif, M. Cherif and A. Boudabous, 2001. Microbial characterization during composting of municipal solid waste. Bioresour. Technol., 80: 217-225. http://www.ncbi.nlm.nih.gov/pubmed/11601546

8. Tiwari, V.N., A.N. Pathak and L.K. Ehri, 1989. Effect of cattle dung and rock phosphate on composting of wool waste. Biol. Wastes, 27: $237-241$.

http://www.fao.org/agris/search/display.do?f=./199 0/v1607/GB8901949.xml;GB8901949

9. Thompson, L.M. and F.R. Troeh, 1978. Soils and Soil Fertility. McGraw Hill, New York, pp: 516.

10. Radhakrishna, D., A.N. Balakrishna, A.M. Krishnappa and T.K.S. Gowda, 1995. Production and evaluation of phosphocomposts from organic wastes with rock phosphate. Proceeding of the 36th Annual Conference on AMI, Mar. 6-8, Hissar, pp: 122.

11. Sincero, A.P. and G.A. Sincero, 1996. Environmental Engineering. Prentice- Hall Inc., pp: 386-387.

12. Landerth, R.E. and P.A. Rebers, 1996. Municipal Solid Wastes: Problems and Solutions. Lewis Publishers, pp: 83-98.

13. Haug, R.T., 1991. Compost Engineering: principals and Practice. CRC Press, pp: 224.

14. Davis, M.L. and D.A. Cornwell, 1998. Introduction to Environmental Engineering. 3rd Edn., Mc GrawHill Inc., pp: 683-89.

15. World Bank, 1987. Integrated resource recoveryThe co-composting of domestic solid waste and Human wastes. USA.

16. Markel, Y.A., 1981. Managing Livestock Wastes. AVI Publishing Co., pp: 14-334. 